\title{
Public procurement and the erosion of the EU social model: Outline of a Polanyian perspective and the emerging regulatory role of human rights
}

\section{Claire Methven O'Brien and Olga Martin-Ortega}

\author{
Chapter 9 in MARTÍN RODRÍGUEZ PABLO JESÚS and HINOJOSA MARTÍNEZ \\ LUIS MIGUEL (editors), International Market Regulation and the Erosion of the \\ European Social and Political Model (forthcoming 2019, ThomsonReuters).
}

\begin{abstract}
States influence markets not just as regulators but also through their purchasing activity. However, governments are implicated in human and labour rights breaches via their purchasing relationships. Such supply chain abuses contradict basic assumptions of the European social model reflected in Europe-wide fundamental rights standards as well as domestic constitutional orders. Until now, EU procurement laws and policies exerted a 'chilling effect' on human rights and sustainability efforts by European public buyers. Yet a nascent movement has started to challenge orthodox reluctance to accept that the scope of rules based on competition and "efficiency", within the EU order, should be conditioned by states' obligations to secure respect for inalienable human rights and minimum labour standards. Public procurement thus serves as one plane for the playing out of continuing tensions between the predominantly competitive logic of international market regulation and Europe's social and human rights values. In this chapter we seek to demonstrate this dynamic while arguing for measures to ensure a rebalancing in this ongoing contest towards protection of the European social model.

Section 2 sketches the contours of public procurement law, with a focus on the EU. Section 3 highlights states' contrasting duties to protect human rights arising under international treaties and new norms on business, human rights, supply chains and sustainability that articulate these in the procurement context. Section 4 outlines a Polanyian analysis of persisting tensions between competitive logic and human rights values in the public procurement context, an approach that, we contend, illuminates important connections between apparently specialist discussions about public procurement and human rights and today's broader controversies about the social and political sustainability of Europe's integrated market economy. We further illustrate how orthodox, competition-based procurement law perspectives threaten EU procurement law's potential to advance social values in Europe is not merely technical but profoundly political and value-laden. Concluding, Section 5 advocates for the establishment of human rights as an explicit dimension within European sustainable procurement norms.
\end{abstract}

Key words: Procurement, human rights, Polanyi, EU law, Directive 2014/24. 


\title{
Public procurement and the erosion of the EU social model: \\ Outline of a Polanyian perspective and the emerging regulatory role of human rights
}

\author{
Claire Methven O'Brien* and Olga Martin-Ortega $\uparrow$
}

\author{
Chapter 9 in MARTÍN RODRÍGUEZ PABLO JESÚS, HINOJOSA MARTÍNEZ LUIS \\ MIGUEL (editors), International Market Regulation and the Erosion of the European \\ Social and Political Model (forthcoming 2019, ThomsonReuters).
}

\section{Introduction}

States have influence on markets other than via the establishment of the norms and frameworks of international commerce that govern trading relations between private entities. As economic actors, states themselves participate in markets by entering into contracts with private enterprises to purchase goods and services, that is, through public procurement. Specifically, public procurement refers to the purchase by the public sector of the goods and services it needs to carry out its functions ${ }^{1}$. Through public procurement, governments and state agencies purchase a wide range of goods and services, from infrastructure projects and the acquisition of complex weapon systems, to the commissioning of essential public services in the health and social care sector and the purchase of common manufactured or processed goods such as stationery, furniture, uniforms, personal electronic items and foodstuffs.

The economic activity generated by the public purchasing of goods and services accounts for a significant proportion of the overall global economy. World Trade Organisation General Procurement Agreements commitments alone represent around EUR 1.3 trillion in business opportunities worldwide ${ }^{2}$. Amongst OECD states, public procurement accounts, on average, for $12 \% \mathrm{GDP}^{3}$ and at European Union level public procurement accounts for 15-20\% of GDP through spending on services, works and supplies ${ }^{4}$.

Yet it is increasingly recognised that governments are involved in human rights abuses, inside and outside Europe, via their purchasing relationships. Central, subnational and local authorities, as well as international organisations, have all faced recent scandals linked, for example, to forced labour, child labour, unlawful discrimination, excessive working hours, unsafe working conditions and suppression of freedoms of expression and association, across sectors including health and social care, electronics, textiles, construction, information technology and security ${ }^{5}$. Such abuses clearly contradict basic

\footnotetext{
* Chief Adviser, Danish Institute for Human Rights; Honorary Lecturer, University of St. Andrews School of Management (cob@humanrights.dk).

$\uparrow$ Professor of International Law, University of Greenwich (o.martin-ortega@gre.ac.uk).

${ }^{1}$ Sue Arrowsmith \& Peter Kunzlik, Social and Environmental Policies in EU Procurement Law: New Directives and New Directions (CUP 2009), 9.

2 European Commission DG Growth, International Procurement (website) $<$ https://ec.europa.eu/growth/single-market/public-procurement/international_en >.

${ }^{3}$ OECD, Public Procurement Website <http://www.oecd.org/gov/public-procurement/>. All websites accessed 17 September 2018.

${ }^{4}$ European Commission, DG Growth, Public Procurement, < https://ec.europa.eu/growth/singlemarket/publicprocurement_en $\geq$.

${ }^{5}$ For examples, see International Learning Lab on Public Procurement and Human Rights (C. Methven O'Brien et al), Public Procurement and Human Rights: A Survey of Twenty Jurisdictions (July 2016)
} 
assumptions of the European social model, as reflected in Europe-wide fundamental human rights and minimum labour standards ${ }^{6}$. Underpinning such instruments, in turn, are formal commitments and values embodied in domestic constitutional orders of individual European states ${ }^{7}$.

Public procurement does not proceed in isolation from international market rules at national, EU or international levels. Besides national laws, public procurement is subject to regulation via regional regimes, such as the European Union's procurement Directives, ${ }^{8}$ and the World Trade Organisation's Plurilateral Agreement on Government Procurement $(\mathrm{GPA})^{9}$. These are market-making rules, that significantly advance transnational economic integration.

On the other hand, public procurement is now addressed by a range of norms intended to mitigate risks to human rights, social and labour standards posed in the context of transnational market integration. Recent measures such as the UN Guiding Principles on Business and Human Rights ${ }^{10}$ exhort states to realise the goal of corporate respect for human rights, including in the area of public procurement. The OECD Guidelines for Multinational Enterprises in turn align to the UNGPs and assimilate their core concept of corporate human rights "due diligence". A swathe of EU policy instruments refer to the UNGPs and OECD Guidelines, for example, the European Commission's 2011 Communication on Corporate Social Responsibility and the European Council's Strategic Framework and Action Plan on Human Rights and Democracy, amongst others ${ }^{11}$. At

<http://www.hrprocurementlab.org/wp-content/uploads/2016/06/Public-Procurement-and-Human-RightsA-Survey-of-Twenty-Jurisdictions-Final.pdf> and International Corporate Accountability, Turning a Blind Eye: Respecting Human Rights in Government Purchasing (September 2014), $<$ https://www.icar.ngo/publications/2017/1/4/turning-a-blind-eye-respecting-human-rights-ingovernment-purchasing>.

${ }^{6}$ For example, the European Convention on Human Rights, European Social Charter and Charter on Fundamental Rights of the European Union, as well as ILO Core Labour Standards to which all European states subscribe.

${ }^{7}$ See generally S. Douglas-Scott and N. Hatzis (eds), Research Handbook on EU Law and Human Rights (Cheltenham: Edward Elgar, 2017); S. Greer, J. Gerards and R. Slowe, Human Rights in the Council of Europe and the European Union (Cambridge: CUP, 2018).

${ }^{8}$ The European procurement framework is composed by a series of directives: Directive 2014/24 on Public Procurement and Repealing Directive 2004/18 (EU Procurement Directive) [2014] OJ L 94; Directive 2014/25 on Procurement by Entities Operating in the Water, Energy, Transport and Postal Services Sector and repealing Directive 2004/17/EC (Utilities Directive) [2014] OJ LL 94; Directive 2009/81/EC on Defence and Security Procurement OJ L216/76 and Directives 89/665/EEC and 92/13/EEC on Remedies (both amended by Directive 2007/66/EC, OJ L335/31).

${ }^{9}$ Revised Agreement on Government Procurement, March 2012, entered into force on 6 April 2014. The aim of the WTO's GPA system is to liberalise public procurement as an area of international trade by applying the principle of non-discrimination in the conduct of the procurement activities which the Agreement covers and to which states have committed: Maria Anna Corvaglia, 'RegioPost and labour rights conditionality: Comparing the EU procurement regime with the WTO Government Procurement Agreement' in Albert Sanchez-Graells (ed), Smart Public Procurement and Labour Standards. Pushing the discussion after RegioPost (Hart 2017) 246.

${ }^{10} \mathrm{UN}$, Guiding Principles on Business and Human Rights. Implementing the United Nations "Protect, Respect, Remedy" Framework (New York and Geneva: UN, 2011; hereafter 'UNGPs'); see further, UN Human Rights Council, Report of the Special Representative of the Secretary-General on the issue of human rights and transnational corporations and other business enterprises Guiding Principles on Business and Human Rights: Implementing the United Nations 'Protect, Respect and Remedy Framework', UN Doc. $\quad$ A/HRC/17/31, $21 \quad$ March 2011, <https://www.ohchr.org/Documents/Publications/GuidingPrinciplesBusinessHR_EN.pdf >.

${ }^{11}$ European Commission, A renewed EU strategy 2011-14 for Corporate Social Responsibility, COM(2011) 681 final (25 October 2011), 6; Council of the European Union, 'EU Strategic Framework on Human Rights and

Democracy'

$(25$

June

2012), 
member state level, national action plans on business and human rights (NAPs) have been developed as vehicles to promote the implementation of the UNGPs, OECD Guidelines and other responsible business standards. ${ }^{12}$

Moreover, given its scale and market value, public procurement holds enormous potential to shift the behaviour of market actors towards practices supportive of the environmentally and socially sustainable development to which the EU and member states are committed, including via the 2030 Agenda for Sustainable Development and Sustainable Development Goals as reflected, for instance, in the European Commission's 2016 Communication Next steps for a sustainable European future. European action for sustainability and 2017 Regulation to establish a European Fund for Sustainable Development (EFSD) ${ }^{13}$.

Until recently, however, procurement laws and policies, particularly at the EU level, appear to have exerted a 'chilling effect' on human rights and sustainability efforts by European public buyers. In the European setting, innovations intended, for instance, to advance the purchasing of "fair trade" products or to extend "living wage" requirements across governments' domestic supply chains have been deterred by legal challenges based on narrow interpretations of EU procurement rules. Influential analysts of European public procurement law and policy frameworks remain conservative, even sceptical, regarding the compatibility of such measures with procurement law's "primary" goals of competition and equal treatment amongst bidders. They argue, for instance, that references to social labels in purchase specifications, or the exclusion of bidders linked to abusive labour practices, may provide opportunities for unfairness as between bidders, on the basis that public buyers will be unable fully to substantiate their selections amongst companies competing for public contracts ${ }^{14}$. Further, EU Procurement Directives, member states' transposing legislation and official guidance at EU and member state levels relating to the Directives have so far declined to address the implications of the UNGPs in the public procurement context, even if public procurement is recognised as an area requiring attention under almost all EU states' published NAPs.

Yet reluctance to accept that the scope of rules based on competition and "efficiency", within the EU order, should be conditioned by states' obligations to secure respect for inalienable human rights and minimum labour standards are finally being subject to challenge, as evidenced by a growing if still nascent scholarly literature, civil society activism and, not least, the persistence of public buyers, individually and collectively, in innovating new practices that circumvent narrow judicial and policy interpretations of procurement law..

<https://www.consilium.europa.eu/uedocs/cms_data/docs/pressdata/en/foraff/131181.pdf>. See also Council of the EU, 'Council Conclusions on Business and Human Rights', 3477th meeting of the Foreign Affairs Council, 10254/16 (20 June 2016).

${ }^{12}$ See further, National Action Plans on Business and Human Rights, www.globalnaps.org.

${ }^{13}$ E.g. European Commission, Communication from the Commission to the European Parliament, the Council, the European Economic and Social Committee and the Committee of the Regions, Next steps for a sustainable European future. European action for sustainability, 22 November 2016, COM(2016) 739 final; Regulation (EU) 2017/1601 of the European Parliament and of the Council of 26 September 2017 establishing the European Fund for Sustainable Development (EFSD), the EFSD Guarantee and the EFSD Guarantee Fund, OJ 27 September 2017.

${ }^{14}$ E.g. A. Sanchez-Graells, "Public procurement and "core" human rights: A sketch of the European Union legal framework", Ch. 6 in O. Martin-Ortega and C. Methven O'Brien, Public procurement and human rights: Opportunities, risks and dilemmas for the state as buyer (Cheltenham: Edward Elgar, 2019 ); cf. A. Ludlow, "Social procurement: Policy and practice" (2016) 7 European Law Journal 479. 
Public procurement thus serves as one plane for the playing out of continuing tensions between the predominantly competitive logic of international market regulation and Europe's social and human rights values. In this chapter we seek to demonstrate this dynamic and also to argue that human rights should be established as an explicit dimension within European sustainable procurement norms as a step in rebalancing this contest towards protection of the European social model.

Section 2 provides necessary context by sketching the contours of public procurement law, with a focus on the EU. Section 3 highlights states' duties to protect human rights arising under international treaties and new norms on business, human rights, supply chains and sustainability that articulate these in the procurement context. Thus, together, sections 2 and 3 demonstrate the contrasting roles and duties of the state as buyer, given that procurement and human rights norms each "constrain the legal framework governing markets and limit the sovereign powers of the States to regulate them" in contrasting ways ${ }^{15}$. Section 4 outlines a Polanyian analysis of persisting tensions between competitive logic and human rights values in the public procurement context, an approach that, we contend, illuminates important connections between apparently specialist discussions about public procurement and human rights and today's broader controversies about the social and political sustainability of Europe's integrated market economy. We further illustrate how orthodox, competition-based procurement law perspectives threaten EU procurement law's potential to advance social values in Europe, thus demonstrating that "market regulation is not merely technical", as the editors' suggest, but profoundly political and value-laden. Section 5 concludes.

\section{Public procurement law: prioritising economic performance over social protection}

The principal or "primary" policy objectives of public procurement are: a) the achievement of value for money ("efficiency"); b) non-discrimination between tenderers; and c) open competition ${ }^{16}$. In legal terms, procurement comprises three main phases. The first, procurement planning, includes the definition of technical specifications, establishment of award criteria and delineation of contract performance conditions. The second phase is tendering, award and conclusion of the contract, while the third step comprises contract management.

Within procurement law regimes, each of these phases is described by rules intended to promote the principal or "primary" policy objectives mentioned above. Besides national procurement laws, depending on monetary value, subject matter and obligations entered into by the state in question, public procurements may be subject to rules, for instance, under regional regimes (such as the European Union's procurement Directives) ${ }^{17}$ and the World Trade Organisation's Plurilateral Agreement on Government Procurement $(\mathrm{GPA})^{18}$. In the EU, an obligation of non-discrimination means that bids over a certain

\footnotetext{
${ }^{15}$ See Editors' Introduction to this volume.

${ }^{16}$ Sue Arrowsmith, "Horizontal Policies in Public Procurement: A Taxonomy", (2010) 10(2) Journal of Public Procurement 149.

${ }^{17}$ The European procurement framework is composed of a series of directives: Directive 2014/24 on Public Procurement and Repealing Directive 2004/18 (EU Procurement Directive) [2014] OJ L 94; Directive 2014/25 on Procurement by Entities Operating in the Water, Energy, Transport and Postal Services Sector and repealing Directive 2004/17/EC (Utilities Directive) [2014] OJ LL 94; Directive 2009/81/EC on Defence and Security Procurement OJ L216/76 and Directives 89/665/EEC and 92/13/EEC on Remedies (both amended by Directive 2007/66/EC, OJ L335/31).

${ }^{18}$ Revised Agreement on Government Procurement, March 2012, entered into force on 6 April 2014. The aim of the WTO's GPA system is to liberalise public procurement as an area of international trade by
} 
threshold in any member state are open to companies from any other member state on the same conditions that national companies enjoy.

Albeit committed to facilitating the allocation of public contracts based on "best value", as the essence of the market mechanism, such regulatory systems allow government buyers ("contracting authorities") a certain measure of discretion in deviating from decision-making based on price alone. The exact scope and parameters of such discretion are generally determined by a regime-specific balancing between the primary objectives of efficiency, non-discrimination and free competition and contracting authorities' other needs and interests, including horizontal goals.

In parallel with the above "primary" aims, then, governments often use public purchasing to promote other policy objectives, such as local or national industrial and economic development, social inclusion and protection of vulnerable groups and environmental concerns. In the past, these were usually labelled as "secondary" or "complementary" 19 " aims of procurement, on the basis that such objectives were not necessarily connected with public buying's functional objective of obtaining services and products at the lowest price or best "value for money ${ }^{20 "}$. Over time, however, the label "horizontal" emerged as an alternative to this terminology $y^{21}$. Given its implicit rejection of a hierarchy amongst a range of procurement goals that are interdependent as much as they are overlapping, and the case we make below, refuting the legal subordination of human rights to the goal of competition, we adopt this language here.

As did their predecessors, the European Union's 2014 procurement Directives explicitly link the award of public contracts by or on behalf of Member State authorities to compliance with the EU principles of free movement of goods, freedom of establishment and the freedom to provide services, as well as principles deriving therefrom, such as equal treatment, non-discrimination, mutual recognition, proportionality and transparency and, for public contracts above a certain value, the principle of open competition $^{22}$.

Yet at the same time, the 2014 Directives were meant to facilitate greater integration of social and environmental goals as legitimate procurement objectives than was possible under the 2004 Directives which they superceded ${ }^{23}$. Accordingly, the highest available

applying the principle of non-discrimination in the conduct of the procurement activities which the Agreement covers and to which states have committed: Maria Anna Corvaglia, 'RegioPost and labour rights conditionality', 246.

${ }^{19}$ In the context of EU procurement, Cantore and Togan refer to the main objectives of EU procurement policy as being to "increase the efficiency of public spending and support the attainment of the Single Market", while its complementary objectives are "the achievement of common societal goals such as the protection of the environment, higher resource and energy efficiency, combatting climate change, promoting innovation and social inclusion, preventing and fighting corruption and favouritism, and ensuring the best conditions for the provision of high-quality public services"; in addition, the "guiding principles" of EU procurement policy are competition, non-discrimination, transparency and objectivity: Carlo M. Cantore and Sübidey Togan, 'Public Procurement in the EU', in Aris Georgopoulos, Bernard Hoekman and Petros Mavroidis (eds), The Internationalization of Government Procurement Regulation (OUP, 2017), 143.

${ }^{20}$ Arrowsmith and Kunzlik, Social and Environmental Policies in the EU, 9.

${ }^{21}$ See Christopher McCrudden, Buying social justice. Equality, government procurement and legal change (OUP 2007); Arrowsmith and Kunzlik, Social and Environmental Policies in the EU 3-54; Sue Arrowsmith, "Horizontal Policies in Public Procurement"; Maria Anna Corvaglia, Public Procurement and Labour Rights. Towards Coherence in International Instruments of Procurement Regulation (Hart 2017) 46.

${ }^{22}$ EU Procurement Directive, Recital 1.

${ }^{23}$ European Commission, Making Public Procurement work in and for Europe, COM(2017) 572 Final. See further: O. Outhwaite and O. Martin-Ortega, "Human Rights in Global Supply Chains: Corporate Social 
quality and the best price under the broadest possible competition should, at least in the EU setting, no longer mean simply buying the cheapest possible supplies or services ${ }^{24}$. Sustainable public procurement would then appear, on this basis, as an aspiration that has entered the mainstream amongst policy-makers and public buyers. Despite this, protecting competition seems in many ways to survive in the 2014 Directivesand associated national frameworks, ${ }^{25}$ as derogations from which "social" and other horizontal policy objectives still require strong scrutiny and justification.

\section{International market regulation: new norms based on human rights and sustainable development}

Human rights recognise the inalienable dignity and equality of all human beings and their correlate basic entitlements. EU member states have international obligations to respect, protect and promote human rights under both customary international law and treaties. National constitutions in EU member states bind government bodies to honour human rights, as do the foundational legal instruments of supranational and international legal actors, including the $\mathrm{EU}^{26}$. According to such obligations, states must protect, respect and fulfil the human rights - civil, political, economic and social, including labour rights - of persons within their jurisdiction ${ }^{27}$.

Historically, human rights were viewed as guaranteeing dignity and fundamental freedoms against the power of public rather than private actors. Accordingly, human rights laws recognised only states as subjects ${ }^{28}$ and generally did not impose direct obligations or liabilities on non-state actors such as businesses, with few exceptions ${ }^{29}$.

Responsibility and Public Procurement in the European Union" (2016) 10 Human Rights and International Legal Discourse, 41.

${ }^{24}$ M. Andrecka and K. Mitkidis, "Sustainability Requirements in EU Public and Private Procurement: A Right or an Obligation?" 20171 NJCL 57, p.63.

${ }^{25}$ For further discussion of constraints competition imposes on discretion under EU public procurement, see: A. Sanchez-Graells, Public procurement and the EU Competition Rules, 2nd edn, (Oxford: Hart, 2015); S. Bogojevič, X. Groussot and J. Hettne (eds.), Discretion in EU Procurement Law (Oxford: Hart, forthcoming 2019).

${ }^{26}$ See generally S. Douglas-Scott and N. Hatzis (eds), Research Handbook on EU Law and Human Rights (Cheltenham: Edward Elgar, 2017).

${ }^{27}$ Human rights include certain labour rights. The basic labour rights recognised by the International Labour Organisation's Declaration on Fundamental Principles and Rights at Work (1998) are referred to as "Core Labour Standards". These comprise freedom of association and effective recognition of the right to collective bargaining; the elimination of all forms of forced or compulsory labour; the effective abolition of child labour; and the elimination of discrimination in respect of employment and occupation. Core Labour Standards are protected by the following ILO instruments: ILO Convention 87 on Freedom of Association and the Protection of the Right to Organise; ILO Convention 98 on the Right to Organise and Collective Bargaining; ILO Convention 29 on Forced Labour; ILO Convention 105 on the Abolition of Forced Labour; ILO Convention 138 on Minimum Age; ILO Convention 111 on Discrimination (Employment and Occupation); ILO Convention 100 on Equal Remuneration; ILO Convention 182 on Worst Forms of Child Labour. "Labour rights", by contrast, are understood referring to workers' rights as established in national and international law, while "labour or working conditions" refer to the factual conditions under which goods are produced.

${ }^{28}$ R. Higgins, Problems and Process: International Law and How We Use It (Oxford: Clarendon Press, 1995).

${ }^{29}$ For instance, where human rights duties coincide with international criminal or international humanitarian law, such as where a business perpetrates or is complicit in genocide, war crimes or some crimes against humanity. 
However, against the backdrop of globalisation, and "governance gaps ${ }^{30 "}$ " accompanying increased production via transnational supply and value chains, outsourcing and regulatory competition between states, since the 1990s this state-centric focus has been challenged, with the role and responsibilities of business and other non-state actors receiving fresh consideration ${ }^{31}$. So that human rights are effective for rights-holders, states' duty to protect human rights is now widely accepted as extending to taking reasonable steps to prevent harmful actions by third parties, both natural and legal persons, the latter including corporations ${ }^{32}$ both independently and in their capacity as suppliers to government ${ }^{33}$.

New norms and policy developments over the last 20 years have thus increasingly sought to promote "responsible" or "sustainable" global value chains, where human rights are respected and risks of business-related abuses are assessed and addressed, identifying these as critical to achieving sustainable development, inclusive global growth and decent work ${ }^{34}$. Such initiatives strongly emphasise the need for "responsible business conduct" in achieving these goals, that is, business conduct that contributes positively to "economic, environmental and social progress with a view to achieving sustainable development" and avoiding adverse human rights impacts ${ }^{35}$.

Two landmarks in this context are the UNGPs and the 2030 Agenda for Sustainable Development and 17 associated Sustainable Development Goals, which as mentioned in section 1 above, the EU has embraced and promotes via both internal and external legal and policy measures. The UNGPs have become a central reference point in definitions of responsible business. They recognise the "role of business enterprises as specialized organs of society performing specialized functions, required to comply with all applicable laws and to respect human rights ${ }^{36}$ ". They comprise a series of elements intended to regulate the impact of corporate activity on human rights, articulated via a tripartite scheme, the UN Framework on Business and Human Rights, under which states have a duty to protect human rights (Pillar I); businesses have the responsibility to respect human rights, to be fulfilled in particular by undertaking human rights due diligence with regard to their own activities and business relationships (Pillar II); and victims have a right to access an effective remedy for business-related human rights abuses (Pillar III) ${ }^{37}$.

\footnotetext{
${ }^{30}$ UN Human Rights Council, "Protect, Respect and Remedy: a Framework for Business and Human Rights Report of the Special Representative of the Secretary-General on the issue of human rights and transnational corporations and other business enterprises, John Ruggie," UN Doc. A/HRC/8/5, 7 April 2008, p.3 para.3. ${ }^{31}$ P. Alston, Non-State Actors and Human Rights (Oxford: OUP, 2005); A. Clapham, Human Rights Obligations of Non-Sate Actors (Oxford: OUP, 2006).

${ }^{32}$ E.g. Airey v Ireland, App. No. 6289/73, Judgement, 9 October 1979; X and Y v Netherlands, App. No. 8978/80, Judgement, 26 March 1985, para 23. For further authorities and discussion, see C. Methven O'Brien, "The Home State Duty to Regulate the Human Rights Impacts of TNCs Abroad: A Rebuttal", 3 Business and Human Rights Journal 47 (2018), pp.63-64.

${ }^{33}$ For further analysis of state human rights obligations in the procurement context see: $\mathrm{C}$. Methven O'Brien and O. Martin Ortega, "Discretion, divergence, paradox: Public and private supply chain standards on human rights", Ch.9 in S. Bogojevič, X. Groussot and J. Hettne (eds), Discretion in EU Procurement Law (Oxford: Hart, 2019), pp.189-209.

${ }^{34}$ ILO, Decent Work, <https://www.ilo.org/global/topics/decent-work/lang--en/index.htm>.

${ }^{35}$ OECD, Responsible Business Conduct in Government Procurement Practices (OECD June 2017) $<$ http://mneguidelines.oecd.org/Responsible-business-conduct-in-government-procurementpractices.pdf>.

${ }^{36}$ UNGPs, p.1.

${ }^{37}$ UN Human Rights Council, Protect, Respect and Remedy: a Framework for Business and Human Rights, A/HRC/8/5, 7 April 2008.
} 
The UNGPs address public procurement as one dimension of the state duty to protect human rights in its first Pillar. States' duty to protect consists of taking appropriate steps to prevent, investigate, punish and redress business-related human rights abuses through effective policies, legislation, regulation and adjudication (UNGP 1). Principles 5 and 6 consider interactions between states and businesses of a commercial nature. Where states privatise or "contract out" public services, they retain their human rights obligations and must "exercise adequate oversight" to ensure these are met. This includes by ensuring that contracts or enabling legislation communicate the state's expectation that service providers will respect the human rights of service users (UNGP 5). Furthermore, states should promote awareness and respect for human rights by businesses in the context of public procurement (UNGP 6 Commentary). When business activities are undertaken by state-owned or controlled enterprises states should undertake human rights due diligence, implicitly encompassing their purchasing function (UNGP 4). Finally, UNGP 8 calls for "policy coherence," that is, the alignment of goals and practices across governmental departments, agencies and institutions with states' human rights obligations.

Pillar II of the UN "Protect, Respect, Remedy" framework on business and human rights is elaborated by UNGPs 11 to 24, which outline elements of the "corporate responsibility to respect human rights. This responsibility to respect human rights entails that businesses should avoid infringing on the human rights of others as well as address adverse human rights impacts with which they are involved ${ }^{38}$.

Because the corporate responsibility to respect human rights is based on social and political expectations, even if these in turn mirror the norms embodied in human right treaties, it applies across all jurisdictions. Accordingly, wherever they operate, companies should not seek to exploit gaps in domestic laws or their enforcement. They may also need to go further than required by applicable legislation ${ }^{39}$. If national rules and international human rights instruments conflict, a company should use its best efforts to respect internationally recognised rights. If this is not ultimately achievable, it should, at minimum, be able to demonstrate its efforts in this regard ${ }^{40}$.

"Responsible business conduct," understood as business behaviour that avoids, mitigates and addresses adverse human rights impacts in value chains, so "contributing positively to economic, environmental and social progress ${ }^{41}$ " features centrally in a subsequent wave of supply chain initiatives following in the wake of the UNGPs.

In 2011, the OECD aligned its Guidelines for Multinational Enterprises with the UNGPs. As seen above, the UNGPs indicate that companies' responsibility to respect human rights extends beyond their own operations to the activities of business partners, including suppliers and sub-contractors, wherever located. This has, in addition, provided a basis for the development by the OECD of detailed supply chain management guidance by industry sector encompassing human rights, for instance, addressing the banking and

\footnotetext{
${ }^{38}$ UNGP 12 enumerates the human rights instruments containing rights that should be respected, at a minimum, by business enterprises; it further indicates that, based on their particular industry sector and operational context, business enterprises should also consider additional human rights standards, especially where they may impact on groups and populations at risk of vulnerability or marginalisation.

${ }^{39} \mathrm{UN}$, Interpretative Guide, p.77 and UNGP 23 (b).

${ }^{40}$ UNGP 23, Commentary, p.26.

${ }^{41} \mathrm{OECD}$, Responsible business conduct in government procurement practices, available at: $<$ http://mneguidelines.oecd.org/Responsible-business-conduct-in-government-procurementpractices.pdf $>$.
} 
financial sectors, footwear and apparel, beyond its prior focus on precious metals ${ }^{42}$. Most recently, it has issued comprehensive "responsible business conduct" due diligence guidance $^{43}$. Multi-stakeholder initiatives, industry associations and governments have likewise produced guidance to support implementation of human rights due diligence on a sector-specific basis. The Council of Europe, principal custodian of European human rights instruments, has also aligned itself with the UNGPs ${ }^{44}$.

In the EU context, the "responsible management of global supply chains" has been identified as essential "to align trade policy with European values ${ }^{45}$." The EU was a keen promoter of voluntary corporate social responsibility which it made part of itsgrowth strategy since the early 2000s. More recently, alignment with the UNGPs became integral to the European Commission's last Corporate Social Responsibility Strategy, published in 2011. Under the Strategy, to identify, prevent and mitigate their possible adverse impacts, large enterprises, and enterprises at particular risk of having such impacts, are encouraged to carry out risk-based due diligence, including through their supply chains.

There has thus been, in the European setting, an increased focus on integrating respect for human rights, including but not limited to ILO Core Labour Standards, into company supply chain standards and management, which has triggered inter alia the development of binding obligations in the context of EU measures addressing so-called conflict minerals, the timber trade and non-financial reporting ${ }^{46}$. Responsible global value chains have become a central theme across EU policy instruments and mechanisms touching on sustainable development and the SDGs ${ }^{47}$. European development finance institutions, including the European Bank for Reconstruction and Development and European Investment Bank have, likewise, lately revised internal policies to introduce references to the UNGPs.

Supplementing and in some instances responding to the above international and regional initiatives, national governments have adopted standards embodying requirements on companies to undertake human rights due diligence across the supply chain. These include new legislation requiring companies to disclose information on their supply chain

42 See further: <http://www.oecd.org/investment/due-diligence-guidance-for-responsible-businessconduct.htm>.

${ }^{43}$ OECD, Due Diligence Guidance for Responsible Business Conduct (Paris: OECD, 2017).

${ }^{44}$ Council of Europe Recommendation CM/Rec(2016)3 of the Committee of Ministers to Member States on Human Rights and Business < https://edoc.coe.int/en/fundamental-freedoms/7302-human-rights-andbusiness-recommendation-cmrec20163-of-the-committee-of-ministers-to-member-states.html >.

${ }^{45}$ European Commission, Trade for All: Towards a more responsible trade and investment policy (COM(2015) 0497), 4.2.3.

${ }^{46}$ Regulation (EU) No. 2017/821 of the European Parliament and the Council of 17 May 2017 laying down supply chain due diligence obligations for Union importers of tin, tantalum and tungsten, their ores and gold originating from conflict-affected and high r-risks areas; Regulation (EU) No. 978/2012 of the European Parliament and of the Council of 20 October 2010 laying down the obligations of operators who place timber and timber products on the market; Directive 2014/95/EU of the European Parliament and of the Council of 22 October 2014 amending Directive 2013/34/EU as regards disclosure of non-financial and diversity information by certain large undertaking and groups, respectively.

${ }^{47}$ European Commission, Communication from the Commission to the European Parliament, the Council, the European Economic and Social Committee and the Committee of the Regions. A renewed EU strategy 2011-14 for Corporate Social Responsibility, COM(2011) 681 final, p.6; See e.g. European Commission, Communication from the Commission to the European Parliament, the Council, the European Economic and Social Committee and the Committee of the Regions, Next steps for a sustainable European future. European action for sustainability, 22 November 2016, COM(2016) 739 final; Regulation (EU) 2017/1601 of the European Parliament and of the Council of 26 September 2017 establishing the European Fund for Sustainable Development (EFSD), the EFSD Guarantee and the EFSD Guarantee Fund, OJ 27 September 2017. 
and their efforts to perform human rights due diligence in the United States, United Kingdom and France ${ }^{48}$. Besides, twenty-one EU governments so far have adopted National Action Plans on Business and Human Rights, of which twenty address public procurement explicitly ${ }^{49}$.

The U.K.'s revised NAP commits "to review the degree to which the activities of U.K. State-owned, controlled or supported enterprises, and of State contracting and purchasing of goods and services are executed with respect for human rights, and make recommendations to ensure compliance with the UNGPs ${ }^{50}$." The Dutch government in its NAP asserts that government suppliers should perform risk analysis to show that they respect human rights in accordance with the UNGPs, and commits to undertake an evaluation of its sustainable procurement policy's social conditions for consistency with the OECD Guidelines for Multinational Enterprises and the UNGPs. ${ }^{51}$ Denmark's NAP highlights that public authorities should assume social responsibility relating to human rights as well as environmental, social, and economic conditions. It further invites Danish municipalities and regions to jointly prepare guidelines for public authorities on how to avoid adverse impacts as a result of purchasing ${ }^{52}$. The NAP of the Czech Republic tasks its Ministry of Regional Development to incorporate human rights issues into new guidance being developed and to incorporate information on the social and human rights context of public contracts and to take these issues into account into training courses for contracting authorities by end $2018 .^{53}$

Turning to the 2030 Agenda for Sustainable Development, this aims to provide a comprehensive and universal platform for development policy and programmes encompassing the environmental, social and economic dimensions of sustainable development. The SDGs accordingly embrace issues including poverty, hunger, health, education, global warming, gender equality, water, sanitation, energy, urbanisation, environment and social justice. The 2030 Agenda and SDGs reflect the role of governments as "megaconsumers," with purchasing power that can shift markets towards sustainable production ${ }^{54}$. UN Sustainable Development Goal 12 sets new objectives on public procurement as part of the drive towards sustainable production and consumption

\footnotetext{
${ }^{48}$ Loi no. 2017-399 du 27 Mars 2017 relative au devoir de vigilance des sociétés mères et des entreprises donneuses d'ordre, $<$ https://www.legifrance.gouv.fr/affichTexte.do?cidTexte=JORFTEXT000034290626\&categorieLien=id $>$ (accessed 4 April 2017); UK Modern Slavery Act 2015,

<http://www.legislation.gov.uk/ukpga/2015/30/contents/enacted>; California Transparency in

Supply Chains Act 2010, <https://oag.ca.gov/SB657 2 .

${ }^{49}$ Danish Institute for Human Rights (DIHR), National Action Plans on Business and Human Rights, Public Procurement: < https://globalnaps.org/issue/public-procurement/>.

${ }^{50}$ U.K. Foreign \& Commonwealth Office, Good Business: Implementing the UN Guiding Principles on Business and Human Rights 9 (2013), available at <https://www.gov.uk/government/uploads/system/uploads/attachment_data/file/236901/BHR_Action_Pla n_-_final_online_version_1_.pdf $\geq$ [hereinafter U.K. NAP].

${ }^{51}$ Dutch Ministry of Foreign Affairs, National Action Plan on Business and Human Rights (Apr. 2014), available at <http://businesshumanrights.org/sites/default/files/documents/netherlands-national-actionplan.pdf $\geq$ [hereinafter Dutch NAP]; Sustainable development and policy House of Representatives 30 196, no. 33, May 2008, 5.

${ }^{52}$ Government of Denmark, Danish National Action Plan-Implementation of the UN Guiding Principles on Business and Human Rights 13 (2014), available at <http://www.ohchr.org/Documents/Issues/Business/NationalPlans/Denmark_NationalPlanBHR.pdf $\geq$ [hereinafter Danish NAP].

${ }^{53}$ National Action Plans on Business and Human Rights, What National Action Plans say on Public procurement, Czech Republic, accessible via: <https://globalnaps.org/issue/public-procurement/ $\geq$.

${ }^{54}$ UNGA, Transforming our world: the 2030 Agenda for Sustainable Development.
} 
and more inclusive economies. It calls on all countries to promote sustainable public procurement practices and to implement sustainable public procurement policies and action plans. Each SDG is articulated through a series of more specific targets. Under SDG 12, Target 12.1 is to implement the 10-year framework of programmes on sustainable consumption and production, with developed countries taking the lead; Target 12.6 is to encourage companies, especially large and transnational companies, to adopt sustainable practices and to integrate sustainability information into the reporting cycle; and Target 12.7 is to promote public procurement practices that are sustainable, in accordance with national policies and priorities ${ }^{55}$. Amongst governments of the global south and global north, efforts are underway to align development planning and development assistance policies and programmes with the SDGs.

To sum up, the SDGs reinforce, at the level of international policy, the role and significance of public purchasing in the context of sustainable, human rights-based development ${ }^{56}$; the UNGPs counsel policy coherence and a holistic integration of human rights into public procurement; and both UNGPs and SDGs address themselves to states and businesses, recognising differentiated but often overlapping functional roles. Finally, to reiterate, from a human rights point of view, the state and its contracting authorities have not only a discretionary capacity to protect human rights through public procurement, but a legally-based duty to do so. Thus, to conclude, human rights laws and sustainable development standards have by now assumed a new role as a source of international market regulation, including in the sphere of public procurement.

\section{Public procurement and Europe's social and political model: A Polynian perspective}

By contrast, as noted in section 2 above, the greater emphasis laid in procurement law regimes, including the WTO and EU systems, on safeguarding the achievement of their primary, competition-focused objectives still tends to narrow public buyers' discretion to advance "non-economic" horizontal aims. Scope to select suppliers based on the extent to which their products or production processes can be said to respect human rights remains curtailed. Significant strands of scholarly opinion continue to underscore the role of procurement law in protecting suppliers (from decisions which might be taken under such discretion on the basis of incomplete, inadequate or false information) rather than protecting workers or others harmed by business activities ${ }^{57}$. In short, protecting competition and market-based ordering seem to remain paramount goals in public procurement law frameworks - an important branch of international market regulation as derogations from which "social" and other horizontal policy objectives still require justification $^{58}$.

\footnotetext{
${ }^{55}$ UNGA, Transforming our world, Goal $12<$ https://sustainabledevelopment.un.org/sdg12>.

${ }^{56} \mathrm{C}$. Methven O'Brien and O. Martin-Ortega "The SDGs, human rights and public procurement: An urgent need for policy coherence' in UN Office for Project Services (ed.), High Impact Procurement. Supporting Sustainable Development. Thematic Supplement to the 2016 Annual Statistical Report on United Nations Procurement: Procurement and the 2030 Agenda (Copenhagen: UNOPS, 2017), <https://content.unops.org/publications/ASR/ASR-supplement-2016_EN.pdf?mtime=20171214185155>.

${ }^{57}$ See for example Sanchez-Graells, 'Public procurement and 'core' human rights'; cf. Sjåfjell and Wiesbrock 'Why should public procurement be about sustainability?' 234.

${ }^{58}$ See generally, Sanchez-Graells, Public procurement and the EU competition rules, 2nd edn (Hart, 2015), ch 5, for discussion on how competition constrains the exercise of discretion in EU public procurement. Cf. Olga Martin-Ortega and Claire Methven O'Brien, 'Advancing Respect for Labour Rights Globally through Public Procurement' (2017) 5(4) Politics and Governance, 69-79.
} 
Public procurement processes thus provide an arena to observe the current interplay between law, liberal markets, human rights and the quest for sustainability. In this section, we set these interactions in a broader theoretical context, by starting to develop the contours of a Polanyian analysis of the relationship between human rights and public procurement.

Economic activity has long been and must remain integral to societal advancement. Yet liberal markets have their pathologies. Karl Polanyi diagnosed a tendency in modern capitalist economies towards the "dis-embedding" of markets ${ }^{59}$. A gradual transition whereby social relations come to be defined by economic logic, rather than ethical or community values, if left unfettered, this process can entail catastrophic consequences. The steady commodification of labour and land in a price-regulated system, according to Polanyi, turns real humans into "dislocated objects of market volatility ${ }^{60}$ ". In turn, this may trigger governments to adopt protectionist measures. Yet, ineffective in themselves in restoring social balance in a context of continuing international trade, these may lead merely to deeper and more prolonged economic crises. As twentieth century Europe witnessed, this can increase the likelihood, eventually, of a "great transformation," from democracy into full-blown authoritarianism, aggressive nationalism and inter-state conflict.

Yet it need not be and is not always so. Polanyi also identified throughout history evidence of a "re-embedding" counter movement: spontaneous and scattered but still potentially influential political impulses challenging market hegemony and aiming both to re-assert the human character of labour and to safeguard the commons from depredation. Far from a perfect embodiment of either market or social values, then, liberal economies and their institutions - amongst them their legal systems, and public procurement law as one branch thereof - rather represent a multiplicity of sites where a clash of principles plays out sporadically. Polanyi called this mutual contestation of tendencies towards autonomisation of the economy, on one hand, and defence of social and environmental sustainability, on the other, the "double movement ${ }^{61}$ ".

Polanyi's work has lately enjoyed a renaissance ${ }^{62}$. It is not hard to see why. As consumption and debt-based economic growth models have spread around the world, their accumulating impacts have come to threaten the biosphere, just as their recent crises have imperilled established economic, political and social institutions ${ }^{63}$. Besides such system-level risks, they impose acute local burdens on specific workers and communities, for instance, in the form of pollution and its health consequences, ecosystem destruction and occupational hazard, whose distribution across global society remains profoundly asymmetric. As popular recognition dawns that planetary boundaries are not elastic, the quest for a worldwide transition to environmental and socially sustainable economies has

\footnotetext{
${ }^{59}$ Karl Polanyi, The Great Transformation: The Political and Economic Origins of our Time (1944) (Boston MA: Beacon Press, [1944] (2001).

${ }^{60}$ Alexander Ebner, "Transnational Markets and the Polanyi Problem" in Christian Joerges and Josef Falke (eds), Karl Polanyi, Globalisation and the Potential of Law in Transnational Markets (Hart 2011) 19-40, 24.

${ }^{61}$ Ebner, "Transnational Markets", 33-39.

${ }^{62}$ E.g. Christian Joerges and Josef Falke (eds), Karl Polanyi, Globalisation and the Potential of Law in Transnational Markets (Hart 2011); Special Issue Economy and Society (2014) 43 New Directions in Polanyian Scholarship; Towards an Economic Sociology of Law, (2013) 40 (1) Journal of Law and Society. ${ }^{63}$ See further, Steven Klein, “The Power of Money: Critical Theory, Democracy, and Capitalism”, available at SSRN:<https://papers.ssrn.com/sol3/papers.cfm?abstract_id=3254451 2 .
} 
become a topic of growing concern for international as well as domestic institutions and policy instruments, ${ }^{64}$ reaching its latest climax in the 2030 Agenda and SDGs.

Human rights norms and narratives play an increasingly important role in this context. Though they remain themselves contested, their essential commitments to equal rights and dignity for all are still a powerful tool in pinpointing injustices in the status quo, triggering the imagination of alternative social arrangements, and encouraging progressive social change (or at least, non-regression) across an ever-expanding sphere of government and market activity. The "human rights based approach to development", for instance, can be seen as one strand of a re-embedding reaction against the economic growth paradigms, including structural adjustment policies, that animated international development actors and their programmes until the 1990s, accompanied by various disastrous results ${ }^{65}$.

In like manner, Polanyian precepts offer an interpretation of the nascent field of business and human rights ${ }^{66}$. Acknowledging, let alone redressing, abuses by corporate actors was until recently formally precluded by international law's Westphalian frame. Still, at least since the 1990s, grassroots human rights activists have relentlessly highlighted the unacceptable moral contradictions this position entails, given the substantive equivalence of state and non-state abuses from the perspective of human subjects. Amongst other things, this has yielded recognition of the "corporate responsibility to respect human rights $^{67}$ ". If a fudge, from a doctrinal standpoint, ${ }^{68}$ while also far from complete as a decommodifying initiative in Polanyian terms, it nevertheless represents an important gesture towards recalibrating the balance between social protection and market rationality in the transnational sphere ${ }^{69}$.

How does this analysis connect with public procurement? Public procurement rules, especially those set and applied at regional and international levels, can be seen as performing a market-making or market-enhancing function (consider, for instance, rules to limit information asymmetries between bidders in a tender process). To substitute price-based decision-making, a dis-embedding manoeuvre in Polanyian terms, for the award of public contracts based on a preference for local suppliers ("discrimination"), or other extraneous considerations, such as corruption, is the core aim of such regimes. It is also one which is, in important settings such as the EU, still pursued at a high cost in terms of government buyers' formal legal discretion to advance the social protection of their own or other states' workers, despite recent innovations, such as the most economically advantageous tender (MEAT) ${ }^{70}$.

\footnotetext{
${ }^{64}$ The concept of planetary boundaries, as defined by Sjafell and Weisbrock, embodies the "fundamental recognition of non-negotiable ecological limits and should form the space within which all economic and social development is to take place": Sjafell and Wiesbrock, "Why should public procurement be about sustainability?" 14.

${ }^{65}$ See further Mac Darrow and Tomas Amparo "Power, capture and conflict: A call for human rights accountability in development cooperation” 2005 27(2) Human Rights Quarterly 471-538; Paul Nelson and Ellen Dorsey, "Who practices rights-based development? A progress report on work at the nexus of human rights and development?" (2018) 104 World Development 87-107.

${ }^{66}$ See further Claire Methven O’Brien, "The UN Special Representative on Business and Human Rights: Re-embedding or Dis-embedding Transnational Markets?" in Joerges and Falk (eds), Karl Polanyi, 323358 for a fuller analysis, and qualified conclusions on the "re-embedding" function of the UNGPs.

${ }^{67} \mathrm{UNHRC}$, Protect, Respect and Remedy: a Framework for Business and Human Rights, A/HRC/8/5, 7 April 2008 Pillar 2 "Corporate Responsibility to Respect".

${ }^{68}$ Claire Methven O’Brien and Sumithra Dhanarajan, "The Corporate Responsibility to Respect: A Status Review" (2016) 29(4) Accounting, Auditing and Accountability Journal 542-567.

${ }^{69}$ Methven O'Brien, "The UN Special Representative".

${ }^{70}$ See Albert Sanchez-Graells, 'Public procurement and 'core' human rights', 8-10.
} 
Yet faint signs of a Polanyian counter-movement can also be traced through the various modest concessions to labour and environment that were earlier incorporated into public procurement rules, especially in the context of the EU, as previously noted. Likewise, they can be seen in the terms of domestic procurement regimes that authorise, to a greater or lesser extent (and albeit typically in second place to the objectives of competition, efficiency and non-discrimination, in terms of lexical hierarchy) the practice of "buying social $^{71} "$.

Historically, that social protectionist impulse in public procurement drew authority from and was articulated via local political narratives, for instance, around labour market inclusion for vulnerable or marginalised groups ${ }^{72}$. Today, as we enter an era of greater "re-bordering" in international trade, such narratives are in some places enjoying a resurgence ${ }^{73}$. At the same time, however, public procurement rules and practices are increasingly challenged, and subject to re-appraisal, with reference to universal human rights and the corresponding duties of states and responsibilities of corporations, mirroring the increasing role of international and transnational procurement regulation and governance ${ }^{74}$.

\section{Conclusion: Re-embedding EU procurement law through human rights}

To date, actually transacted changes in procurement laws, their interpretation and application that can be traced back to human rights based rules or arguments are, on a global view, incremental, inchoate and patchy. For human rights scholars and activists, this mixed picture is a familiar one. The implications of international commitments assumed by governments take decades to percolate to the front-line public authorities, and corporations, with whom most rights-holders daily interface, and progress comes in spurts, with many steps backwards on the way. Meanwhile, even if many procurement frameworks today are transitioning to the pursuit of value for money on a lifetime basis ${ }^{75}$, in the procurement context other sources of international and regional market regulation, for instance, deriving from international economic law or European Union legal standards, may seem to have more immediate and deleterious effects, when seen from a social protection standpoint.

This is implicit, for instance, in the widely accepted definition of social procurement advanced by the European Commission in its Buying Social Guide ${ }^{76}$. Here, socially responsible public procurement is described as procurement that "takes into account one or more of the following social considerations: promoting employment opportunities, decent work, compliance with social and labour rights, social inclusion (including persons with disabilities), equal opportunities, accessibility design for all, taking account of sustainability criteria, including ethical trade issues and wider voluntary compliance with corporate social responsibility (CSR), while observing the principles enshrined in the

\footnotetext{
${ }^{71}$ Christopher McCrudden, Buying social justice. See also, Claire Methven O’Brien and Olga Martin Ortega, "Discretion, divergence, paradox".

${ }^{72}$ McCrudden, Buying social justice.

${ }^{73}$ See e.g. "Blue Passports and public procurement", The Financial Times, 22 March 2018, <https://www.ft.com/content/7fcd730e-2ddd-11e8-9b4b-bc4b9f08f381; European Parliament votes in favour of the revision on posted workers, EurActiv, 30 May 2018 $\geq$.

${ }^{74}$ Aris Georgeopoulos, Bernard Hoekman and Petros Mavroidis (eds), The Internationalization of Government Procurement Regulation (OUP 2017).

${ }^{75}$ Marta Andrecka and Katerina Mitkidis, "Sustainability Requirements in EU Public and Private Procurement- A Right or an Obligation? 20171 NJCL 57.

${ }^{76}$ European Commission, Buying Social. A Guide to Taking Account of Social Considerations in Public Procurement (2011) <http://ec.europa.eu/social/main.jsp?langId=en\&catId=89\&newsId=978> .
} 
Treaty for the European Union (TFEU) and the Procurement Directives ${ }^{77}$ ". Human rights appears in the Guide as one of "the social considerations" which "could be relevant for procurement," without further specifying the scope of human rights duties of public buyers and how they may be integrated in the interpretation and application of the EU procurement regime ${ }^{78}$.

The previous sections have demonstrated that public procurement is not only an instrument of economic performance but a key tool for the definition and implementation of social policies, including the fulfilment of state obligations to protect human rights through all their activities. Public procurement is therefore a cornerstone of the definition of social and political models and should be taken into account when discussing how these are eroded by international economic processes and decisions.

Thus, we suggest, an important precondition of protecting Europe's social and political model is a transition to a new public procurement paradigm, distinct from the prevailing lens and terminology of "social" or "sustainable procurement", to one whereby, as we have advocated elsewhere, "sustainable" public procurement is understood as procurement that respects human rights "and which promote[s] sustainable development and responsible business conduct through the practice of risk-based supply chain due diligence to identify, prevent, mitigate and remedy potential and actual adverse impacts on human rights as well as environmental and social concerns, both at domestic level and beyond, observing the principles enshrined in the International Bill of Rights, the International Labour Organisation Core Labour Rights Standards, the United Nations Guiding Principles on Business and Human Rights and the Sustainable Development Goals ${ }^{79}$."

Making this transition ought to help, as others have urged, "to ...ensure that public procurement rules and practice contribute to global sustainability, to a balancing of social and economic development, ensuring the fundamental of quality of life for all people, within the ecological boundaries of the planet we live on. What greater goal could here be? ${ }^{80 "}$

\footnotetext{
${ }^{77}$ European Commission, Buying Social, p.5 (emphasis added). At time of writing, the Commission is developing new social procurement guidance. In this context the current authors have advocated a more explicit inclusion of a human rights dimension and proposed a new definition of socially responsible procurement: C. Methven O'Brien and O. Martin-Ortega, Guidance on Socially Responsible Public Procurement: Response to Consultation of the European Commission by the International Learning Lab on Procurement and Human Rights, available at: <http://www.hrprocurementlab.org/blog/articles/guidance-on-socially-responsible-public-procurementresponse-to-consultation-of-the-european-commission-by-the-international-learning-lab-on-procurementand-human-rights/>.

${ }^{78}$ The guide merely refers to "protecting against human rights abuse and encouraging respect for human rights" while other social considerations listed in the Guide are more fully elaborated: European Commission, Buying Social, 9.

${ }^{79} \mathrm{Ibid}$, this is the definition we suggested to the European Commission in response to their call for consultations to update the guidance Buying Social. A Guide to Taking Account of Social Considerations in Public Procurement 2010.

${ }^{80}$ Anja Wiesbrock and Beate Sjåfjell, "Public Procurement's Potential for Sustainability" in Beate Sjåfjell and Anja Wiesbrock (eds), Sustainable Public Procurement under EU Law. New Perspectives on the State as a Stakeholder (CUP 2016), 242.
} 